\title{
DEVELOPMENT OF A COMPONENT BASED MACHINING CENTER SELECTION MODEL USING AHP
}

\author{
Yusuf Tansel Ic ${ }^{1}$, Mustafa Yurdakul ${ }^{2}$, Ergün Eraslan ${ }^{1 *}$ \\ ${ }^{1}$ Department of Industrial Engineering, Baskent University, Ankara, Turkey \\ E-mail: ytansel@,baskent.edu.tr; eraslan@,baskent.edu.tr \\ ${ }^{2}$ Department of Mechanical Engineering, Gazi University, Ankara, Turkey \\ E-mail: yurdakul@gazi.edu.tr
}

\begin{abstract}
Machining centers are widely used in manufacturing companies all over the world. Since investments in machining centers are long-term and expensive, selection of the most appropriate machining center is an important decision for manufacturing companies. There are a great deal of efforts spent in developing crisp and fuzzy multi criteria decision making (MCDM) models that use technical specifications provided by the machining center manufacturers such as, axis size, power, spindle speed, tolerance, repeatability, cutting tool change time, number of cutting tools along with other economical and commercial factors. However, the technical specifications are directly taken from machining center manufacturers' catalogues without checking their correctness, adequacies or ability to represent the areas that are used to measure. In such a case, one can not be sure whether the outcomes are sound or not without a detailed check of technical specifications, which can only be performed after actual usage of the machine itself. To overcome all such problems, an Analytic Hierachy Process (AHP) model that evaluates the machining center components is developed in this paper. It should be noted that, the differences in machining center components are the causes of the differences in technical specification values of machining centers. The new component-based AHP model is then compared with a MCDM model that uses technical specification values.
\end{abstract}

Keywords: Machining Center Selection, Analytic Hierarchy Process (AHP), Machining Center Components.

\section{Introduction}

The machining centers are gaining acceptance in manufacturing industries. However, their selection is becoming more difficult with the increased number of available types and models. In the literature, there are various models developed to help manufacturing companies in machining center selection problems. For example, Vasilash (1997) developed a computer program called "machining center selector" which obtains a feasible set of machining centers by searching the data base and eliminating unsuitable ones. In other studies, Sun (2002) presents a machining center selection methodology that uses Data Envelopment Analysis and Georgakellos (2005) proposes a scoring model that incorporates technical and commercial characteristics of machines. In the literature, Multi Criteria Decision Making (MCDM) methods especially Analytic Hierarchy Process (AHP) and Analytic Network Process (ANP) are also used in selection of machining centers (Arslan et al., 2002; Lin and Yang, 1996; Çimren et al., 2004; Oeltjenbruns et al., 1995; Yurdakul, 2004; İç and Yurdakul, 2009; Ayağ and Özdemir, 2011).

The developed selection models in the literature commonly use technical specification values of machining centers such as table size, axis movement, power, spindle speed, axis speed, tool number, machine size, work piece size, finish tolerances (İç and Yurdakul, 2009; Ayağ and Özdemir, 2011). The specification values used in the models are taken from machining center manufacturers' catalogues. However, some specification values such as accuracy, repeatability, axis velocity are

\footnotetext{
Corresponding author
} 
difficult to measure and their values tend to vary under changing conditions. To the best knowledge of the authors, a study that checks the accuracy of specification values provided by the machining center manufacturers is not available in the literature. It is clear that any error or misinformation in these values will directly affect the ranking results. Instead of using specification values, the components, which are the sources of the differences in the technical specification values, can be incorporated in a multi criteria machining center selection model. With such a model the machining centers are ranked according to the component types they possess avoiding any error or misinformation in the technical specification values provided in machining center builders' catalogues. This paper aims to develop such a model using AHP, which is the the most preferred approach in machining center selection literature since it is simple, easy to use, and capable of forming a hierarchical decision structure. In the following sections, the component based AHP model is developed and then compared with an AHP model that uses technical specifications.

\section{Component types used in machining centers and development of the component based AHP model}

Guides, spindle/bearing, feed drive and structure are the four components that are critical in determining a machining center's performance. To determine performance of a machining center five criteria, namely stiffness, damping capacity, thermal stability, speed capacity and accuracy are selected in this study. The selection criteria and the components are linked together in the developed AHP decision hierarchy to calculate ranking scores of machining centers (Figure 1). However, it is necessary to determine the performance level provided by different component types used in machining centers at each criterion and the component types used in machining centers before calculation of the ranking scores of machining centers. Types of the four components and their performance levels at the selection criteria are summarized in Table 1. The component types used in various machining centers are also provided in Table 2.

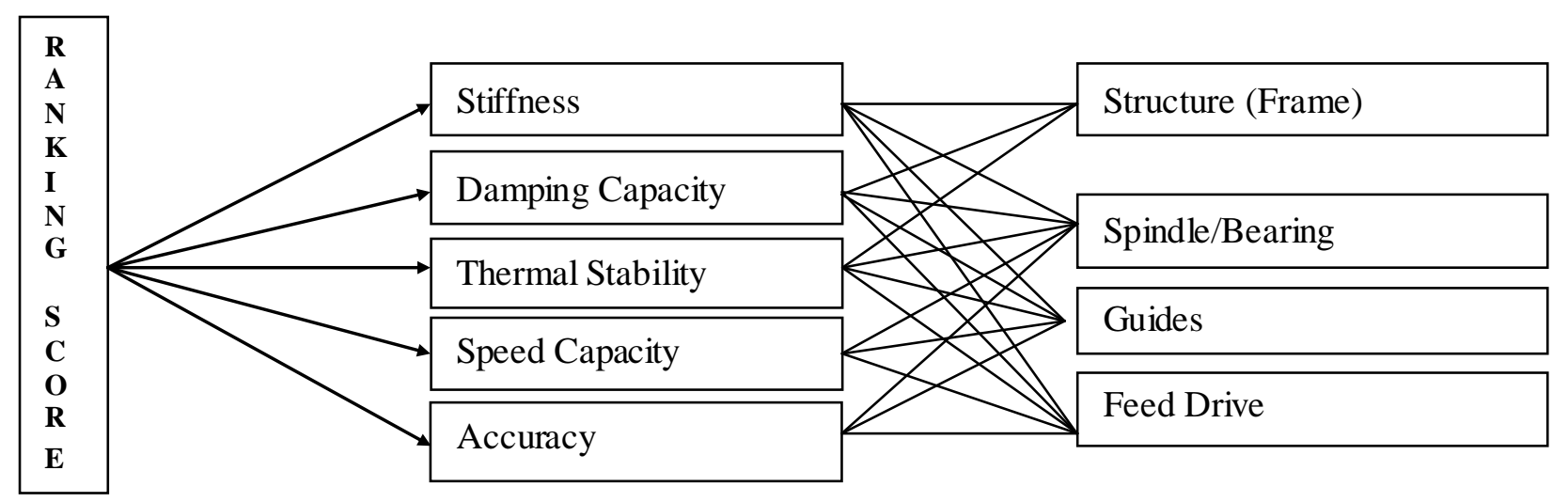

Figure 1. The AHP decision hierarchy

As a first step in obtaining ranking scores of machining centers using the AHP decision hierarchy, the performance scores of machining centers at each component are determined between zero and one based on their component types given in Table 2 and provided in Table 3. In Table 3, the lowest and highest assignable scores are ' 0 ' and ' 1 ' respectively whereas the average performance receives ' 0.5 ' score. Then, the importance weights of components at each criterion and the importance weights of selection criteria are calculated using the AHP approach. Calculation of the importance weights of selection criteria is illustrated in Table 4. The last column of the normalized pairwise comparison matrix provides the weights of selection criteria (Wabalickis, 1987; Cheng and Li, 2001). Once the weights are calculated using the AHP approach, the ranking score of each machining center can be calculated as illustrated in Table 5.

\section{Comparison of component-based AHP model}

The ranking results of the component-based AHP model are then compared with the selection model (MACSEL-MAchining Center SELection) using Spearman's rank correlation test and presented in Table 6 for three specific cases named as 'mass',flexible','sensitive'. 
Table 1. Component types used in machining centers and their performance level (Irath and Romero, 2005; Tlusty, 2000)

\begin{tabular}{|c|c|c|c|}
\hline Component Name & $\begin{array}{l}\text { Interaction/ } \\
\text { Functions }\end{array}$ & Component Types & Performance Le vel at Selection Criteria \\
\hline \multirow{4}{*}{ Guides } & \multirow{4}{*}{$\begin{array}{l}\text { Feed Motion- } \\
\text { Work piece } \\
\text { Surface }\end{array}$} & Box & $\begin{array}{l}\text { High stiffness, high friction, low speed, high wear, good damping } \\
\text { capacity, difficult maintenance and repair. }\end{array}$ \\
\hline & & Linear-Ball Bearing & $\begin{array}{l}\text { Good stiffness, very low friction, very high speed, high accuracy, } \\
\text { good damping capacity, very easy maintenance and repair }\end{array}$ \\
\hline & & Linear-Cylindirical Bearing & $\begin{array}{l}\text { High stiffness, low firiction, high speed, very high accuracy, very } \\
\text { good damping capacity, easy maint enance and repair }\end{array}$ \\
\hline & & Hydrostatic & $\begin{array}{l}\text { Very high loading capacity, no wear, very low friction, difficult and } \\
\text { expensive maintenance and repair }\end{array}$ \\
\hline \multirow{4}{*}{ Spindle/ Bearing } & \multirow{4}{*}{$\begin{array}{l}\text { Tool-Workpiece } \\
\text { Motion }\end{array}$} & Ball Bearing & High speed, good accuracy, low friction \\
\hline & & Angular Contact Ball Bearing & $\begin{array}{l}\text { High speed (requires cooling system), high accuracy, high loading } \\
\text { capacity, high friction. }\end{array}$ \\
\hline & & Cylindirical Bearing & $\begin{array}{l}\text { Good speed capacity, high accuracy, high stiffnes, very high loading } \\
\text { capacity, high damping capacity, high friction. }\end{array}$ \\
\hline & & Hybrid Bearing & Very fast speed, high accuracy, high damping capacity. \\
\hline \multirow{4}{*}{ Feed Drive } & \multirow{4}{*}{$\begin{array}{l}\text { Table and Head } \\
\text { Stock Motion }\end{array}$} & Ball-Screw-Single Nut & High speed, very good accuracy, low friction, low heating. \\
\hline & & Ball-Screw-Double Nut & $\begin{array}{l}\text { Quite good speed, very good accuracy (with proper cooling system), } \\
\text { very high stiffness, high damping capacity, high heat. }\end{array}$ \\
\hline & & $\begin{array}{l}\text { Ball-Screw-Fixed both end/or } \\
\text { Preloaded }\end{array}$ & $\begin{array}{l}\text { Quite good speed, very good accuracy (if a cooling system is used), } \\
\text { very high stiffness, high damping capacity, very high heat ing. }\end{array}$ \\
\hline & & Linear Motor & $\begin{array}{l}\text { Very high speed, very low friction, high accuracy, high positioning, } \\
\text { very easy or no maint enance. }\end{array}$ \\
\hline \multirow[b]{2}{*}{ Structure } & \multirow{2}{*}{$\begin{array}{l}\text { Frame for the } \\
\text { Machining } \\
\text { Center's } \\
\text { Components. }\end{array}$} & Cast-Iron & Cheap and easy to build structure, good damping capacity. \\
\hline & & $\begin{array}{l}\text { Special Design or Special } \\
\text { Materials Used }\end{array}$ & $\begin{array}{l}\text { Better heat dissipation; It is possible to build structures such as } \\
\text { symmetric, bridge type, extra column feeder or double column that } \\
\text { provide increased stiffness, thermal stability and damping capacity. }\end{array}$ \\
\hline
\end{tabular}

Table 2. Component types used in the selected twenty machining centers

\begin{tabular}{|c|c|c|c|c|c|c|}
\hline & MARK & MODEL & Guides & Spindle/Bearing & Feed Drive & Structure \\
\hline 1 & MAZAK & FH8800 & Linear Guide & Ball Bearing, Chiller Unit & Ball Screw & Mehanite Casting \\
\hline 2 & MAZAK & VT C200B & Linear Guide & Ball Bearing & Ball Screw & $\begin{array}{l}\text { Mehanite Casting, } \\
\text { Cooling System }\end{array}$ \\
\hline 3 & MAZAK & NXS5 10CHS & Linear Guide & Ball Bearing, Chiller Unit & Ball Screw & $\begin{array}{l}\text { Mehanite Cast ing, } \\
\text { Cooling System }\end{array}$ \\
\hline 4 & OKUMA & MA550VB & Slide and Roller Way & $\begin{array}{l}\text { Ball Bearing, Oil-Air } \\
\text { Lubrication }\end{array}$ & Ballscrew Cooling System & Mehanite Casting \\
\hline 5 & OKUMA & MB56VA & Linear Guide & $\begin{array}{c}\text { Ball Bearing and TAS-S } \\
\text { Design }\end{array}$ & Ball Screw & TAS-S-Construction \\
\hline 6 & OKUMA & MCV3016 & Linear Guide & $\begin{array}{l}\text { Ball Bearing, Cooling } \\
\text { System }\end{array}$ & Ball Screw & Mehanite Casting \\
\hline 7 & EXCEL & PMC10T24 & Linear Guide & Ball Bearing & Ball Screw Supported Both End & Mehanite Casting \\
\hline 8 & MILLT RONICS & VM25 & Linear Guide & Hybrit Bearing & Ball Screw-x2Anchored & Cast Iron \\
\hline 9 & MILLTRONICS & VM30 & \begin{tabular}{c|} 
Linear Guide \\
\end{tabular} & Triplex Ball Bearing & Ball Screw-x2Anchored & Cast Iron \\
\hline 10 & EAGLE & VMC1300 & \begin{tabular}{|c|} 
Z-Axis:Box Way; X- \\
and Y-axis:Linear Guide
\end{tabular} & $\begin{array}{c}\text { P4 Grade-Angular Cont act } \\
\text { Ball Bearing }\end{array}$ & $\begin{array}{l}\text { Ball Screw is Supported Both } \\
\text { End and Preloaded }\end{array}$ & Cast Iron \\
\hline 11 & CHALLENGER & VM1000 & Box Way & Ball Bearing, Oil Chiller & $\begin{array}{c}\text { Double nut and preload Ball } \\
\text { Screw Used }\end{array}$ & Mehanite Casting \\
\hline 12 & CHALLENGER & VMC1300 & Box Way & Ball Bearing, Oil Chiller & $\begin{array}{c}\text { Double nut and preload Ball } \\
\text { Screw Used }\end{array}$ & Mehanite Casting \\
\hline 13 & FADAL & VMC4020 & $\begin{array}{c}\text { Box Way, Friction Free } \\
\text { Design }\end{array}$ & $\begin{array}{l}\text { Hybrit Bearing, Oil-Air } \\
\text { Lubrication }\end{array}$ & Ball Screw & Cast Iron \\
\hline 14 & FADAL & VMC4525 & $\begin{array}{c}\text { Box Way, Friction Free } \\
\text { Design }\end{array}$ & $\begin{array}{c}\text { Ball Bearing, Cooling } \\
\text { System }\end{array}$ & Ball Screw & Cast Iron \\
\hline 15 & FADAL & VMC3020 & $\begin{array}{c}\text { Box Way, Friction Free } \\
\text { Design }\end{array}$ & $\begin{array}{c}\text { Ball Bearing, Cooling } \\
\text { System }\end{array}$ & Ball Screw & Cast Iron \\
\hline 16 & HYUNDAI & SPT V25 & Linear Guide & Ball Bearing, Chiller Unit & Ball Screw & Bridge \\
\hline 17 & HYUNDAI & SPT V32/405 & Linear Guide & Ball Bearing, Chiller Unit & Ball Screw & Bridge \\
\hline 18 & HYUNDAI & SPT V800 & Linear Guide & Hybrit Bearing & $\begin{array}{l}\text { Ball Screw is Supported Both } \\
\text { End and Preloaded }\end{array}$ & Mehanite Casting \\
\hline 19 & MAT SUURA & HMAX500 & Linear Guide & Hybrit Bearing & $\begin{array}{l}\text { Double Ball Screw and } \\
\text { Ballscrew cooling system }\end{array}$ & Bridge type design \\
\hline 20 & MORISEIKI & NH8000DCG & $\begin{array}{l}\text { Linear Guide-DCG, } \\
\text { Cooling System }\end{array}$ & Ball Bearing, Oil Chiller & $\begin{array}{c}\text { DCG, and Ballscrew cooling } \\
\text { system }\end{array}$ & $\begin{array}{l}\text { DCG and Heat } \\
\text { Symetry Design }\end{array}$ \\
\hline
\end{tabular}


Table 3. Performance scores of the twenty machining centers at five selection criteria

\begin{tabular}{|c|c|c|c|c|c|c|c|c|c|c|c|c|c|c|c|c|c|c|c|c|}
\hline \multirow[b]{2}{*}{ No } & \multirow[b]{2}{*}{ Mark } & \multirow[b]{2}{*}{ Model } & \multicolumn{4}{|c|}{ ST IFFNESS } & \multicolumn{4}{|c|}{ DAMPING } & \multicolumn{4}{|c|}{\begin{tabular}{|l} 
TERMAL \\
ST ABILITY
\end{tabular}} & \multicolumn{3}{|c|}{ ACCURACY } & \multicolumn{3}{|c|}{\begin{tabular}{|l} 
SPEED \\
CAPACITY
\end{tabular}} \\
\hline & & & A & B & $\mathrm{C}$ & $\mathrm{D}$ & A & B & $\mathrm{C}$ & $\mathrm{D}$ & A & B & $\mathrm{C}$ & D & A & B & $\mathrm{C}$ & A & B & $\mathrm{C}$ \\
\hline 1 & MAZAK & FH8800 & 0.7 & 0.4 & 0.4 & 0.5 & 0.7 & 0.4 & 0.7 & 0.8 & 0.7 & 0.9 & 0.4 & 0.7 & 0.7 & 0.6 & 0.4 & 1.0 & 0.9 & 0.4 \\
\hline 2 & MAZAK & VTC200B & 0.7 & 0.4 & 0.4 & 0.5 & 0.7 & 0.4 & 0.7 & 0.8 & 0.7 & 0.7 & 0.4 & 0.5 & 0.7 & 0.4 & 0.4 & 1.0 & 0.7 & 0.4 \\
\hline 3 & MAZAK & NXS5 10CHS & 0.7 & 0.4 & 0.4 & 0.5 & 0.7 & 0.4 & 0.7 & 0.8 & 0.7 & 0.9 & 0.4 & 0.5 & 0.7 & 0.6 & 0.4 & 1.0 & 0.9 & $\overline{0.4}$ \\
\hline 4 & OKUMA & MA550VB & 0.8 & 0.4 & 0.4 & 0.5 & 0.8 & 0.4 & 0.7 & 0.8 & 0.8 & 0.8 & 0.6 & 0.5 & 0.8 & 0.5 & 0.6 & 1.0 & 0.8 & 0.6 \\
\hline 5 & OKUMA & MB56VA & 0.7 & 0.4 & 0.4 & 0.6 & 0.7 & 0.6 & 0.7 & 0.9 & 0.7 & 1.0 & 0.4 & 0.7 & 0.7 & 0.7 & 0.4 & 1.0 & 0.9 & 0.4 \\
\hline 6 & OKUMA & MCV3016 & 0.7 & 0.4 & 0.4 & 0.5 & 0.7 & 0.4 & 0.7 & 0.8 & 0.7 & 0.8 & 0.4 & 0.4 & 0.7 & 0.5 & 0.4 & 1.0 & 0.7 & 0.4 \\
\hline 7 & EXCEL & PMC10T24 & 0.7 & 0.4 & 0.5 & 0.5 & 0.7 & 0.4 & \begin{tabular}{|l|}
0.8 \\
\end{tabular} & 0.8 & 0.7 & 0.7 & 0.5 & 0.4 & 0.7 & 0.4 & 0.5 & 1.0 & 0.7 & 0.3 \\
\hline 8 & MILLTRONICS & VM25 & 0.7 & 1.0 & 0.5 & 0.4 & 0.7 & 0.8 & 0.8 & 0.8 & 0.7 & 1.0 & 0.4 & 0.4 & 0.7 & 1.0 & 0.5 & 1.0 & 1.0 & 0.3 \\
\hline 9 & MILLTRONICS & VM30 & 0.7 & 0.5 & 0.5 & 0.4 & 0.7 & 0.5 & 0.8 & 0.8 & 0.7 & 0.6 & 0.4 & 0.4 & 0.7 & 0.5 & 0.5 & 1.0 & 0.6 & 0.3 \\
\hline 10 & EAGLE & VMC1300 & 0.8 & 0.5 & 0.6 & 0.4 & 0.6 & 0.5 & 0.8 & 0.7 & 0.4 & 0.6 & 0.5 & 0.3 & 0.6 & 0.5 & 0.6 & 0.6 & 0.6 & 0.3 \\
\hline 11 & CHALLENGER & VM1000 & 0.9 & 0.4 & 0.6 & 0.6 & 0.4 & 0.4 & 0.8 & 0.9 & 0.2 & 0.8 & 0.3 & 0.4 & 0.5 & 0.5 & 0.5 & 0.4 & 0.8 & 0.3 \\
\hline 12 & CHALLENGER & VMC1300 & 0.9 & 0.4 & 0.6 & 0.6 & 0.4 & 0.4 & 0.8 & 0.9 & 0.0 & 0.8 & 0.3 & 0.4 & $\overline{0.4}$ & 0.5 & 0.5 & 0.0 & 0.8 & 0.3 \\
\hline 13 & FADAL & VMC4020 & 0.9 & 1.0 & 0.4 & 0.4 & 0.4 & 0.8 & 0.7 & 0.7 & 0.2 & 0.9 & 0.4 & 0.3 & 0.5 & 1.0 & 0.4 & 0.4 & 1.0 & 0.4 \\
\hline 14 & FADAL & VMC4525 & 0.9 & 0.4 & 0.4 & 0.4 & 0.4 & 0.4 & 0.7 & 0.7 & 0.2 & 0.8 & 0.4 & 0.3 & 0.5 & 0.5 & 0.4 & 0.4 & 0.5 & 0.4 \\
\hline 15 & FADAL & VMC3020 & 0.9 & 0.4 & 0.4 & 0.4 & 0.4 & 0.4 & 0.7 & 0.7 & 0.2 & 0.8 & 0.4 & 0.3 & 0.5 & 0.5 & 0.4 & 0.4 & 0.5 & 0.4 \\
\hline 16 & HYUNDAI & SPTV25 & 0.7 & 0.4 & 0.4 & 0.8 & 0.7 & 0.4 & 0.7 & 0.9 & 0.7 & 0.9 & 0.4 & 0.5 & 0.7 & 0.6 & 0.4 & 1.0 & 0.9 & 0.4 \\
\hline 17 & HYUNDAI & SPT V32/405 & 0.7 & 0.4 & 0.4 & 0.8 & 0.7 & 0.4 & 0.7 & 0.9 & 0.7 & 0.9 & 0.4 & 0.5 & 0.7 & \begin{tabular}{|l|}
0.6 \\
\end{tabular} & 0.4 & 1.0 & 0.9 & 0.4 \\
\hline 18 & HYUNDAI & SPT V800 & 0.7 & 1.0 & 0.6 & 0.5 & 0.7 & 0.8 & 0.8 & 0.8 & 0.7 & 1.0 & 0.5 & 0.4 & 0.7 & 1.0 & 0.6 & 1.0 & 1.0 & 0.3 \\
\hline 19 & MAT SUURA & HMAX500 & 0.7 & 1.0 & 0.8 & 0.9 & 0.7 & 0.8 & 0.8 & 0.9 & 0.7 & 1.0 & 0.6 & 0.5 & 0.7 & 1.0 & 0.7 & 1.0 & 1.0 & 0.6 \\
\hline 20 & MORISEIKI & NH8000DCG & 0.9 & 0.4 & 0.8 & 1.0 & 0.8 & 0.4 & \begin{tabular}{|l|}
0.8 \\
\end{tabular} & 1.0 & 0.8 & 0.9 & 0.7 & 0.7 & 0.8 & 0.8 & 0.9 & 1.0 & 0.9 & 0.6 \\
\hline
\end{tabular}

Table 4. Calculation of the importance weights of selection criteria

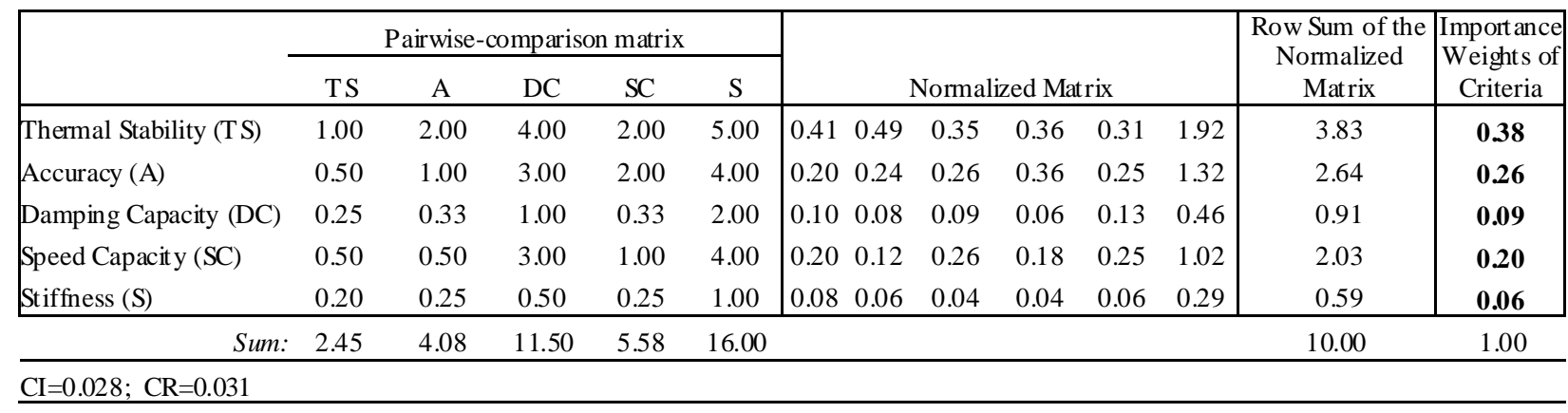

Table 5. Calculation of the MORISEIKI NH8000DCG's ranking score

\begin{tabular}{|l|l|c|c|c|c|}
\hline & & & \multicolumn{2}{|c|}{ Importance Weights of } & \\
Selection Criteria & Components & Performance Score & Component & Selection Crite ria & Global Weight \\
\hline Stiffness & Guides & 0.9 & $\mathbf{0 . 4 6}$ & & 0.024 \\
& Spindle/Bearing & 0.4 & $\mathbf{0 . 0 7}$ & $\mathbf{0 . 0 6}$ & 0.002 \\
& Feed Drive & 0.8 & $\mathbf{0 . 3 1}$ & 0.015 \\
& Structure & 1.0 & $\mathbf{0 . 1 6}$ & & 0.009 \\
\hline Damping Capacity & Guides & 0.8 & $\mathbf{0 . 4 6}$ & & 0.034 \\
& Spindle/Bearing & 0.4 & $\mathbf{0 . 0 7}$ & $\mathbf{0 . 0 9}$ & 0.003 \\
& Feed Drive & 0.8 & $\mathbf{0 . 3 1}$ & & 0.023 \\
& Structure & 1.0 & $\mathbf{0 . 1 6}$ & & 0.014 \\
\hline Thermal Stability & Guides & 0.8 & $\mathbf{0 . 1 6}$ & & 0.048 \\
& Spindle/Bearing & 0.9 & $\mathbf{0 . 4 6}$ & $\mathbf{0 . 3 8}$ & 0.159 \\
& Feed Drive & 0.7 & $\mathbf{0 . 3 1}$ & & 0.083 \\
& Structure & 0.7 & $\mathbf{0 . 0 7}$ & & 0.019 \\
\hline Accuracy & Guides & 0.8 & $\mathbf{0 . 5 7}$ & $\mathbf{0 . 2 6}$ & 0.120 \\
& Spindle/Bearing & 0.8 & $\mathbf{0 . 1 0}$ & $\mathbf{0 . 2 6}$ & 0.021 \\
& Feed Drive & 0.9 & $\mathbf{0 . 3 3}$ & & 0.079 \\
\hline Speed Capacity & Guides & 1.0 & $\mathbf{0 . 5 7}$ & $\mathbf{0 . 2 0}$ & 0.115 \\
& Spindle/Bearing & 0.9 & $\mathbf{0 . 3 3}$ & & 0.061 \\
\hline RANKINGSCORE: & Feed Drive & 0.6 & $\mathbf{0 . 1 0}$ & & $\mathbf{0 . 8 4 1}$ \\
\hline
\end{tabular}


Details of the cases and MACSEL which uses only specification values in its ranking procedure are presented in İç and Yurdakul (2009). The Spearman's rank correlation test calculates the statistical significance values of the differences in the rankings $(Z)$ which are provided in the last row of Table 6. If 0.05 significance level of $\alpha$ which corresponds to 1.645 as the critical $Z$ value is selected, it can be observed that all three $Z$ values (1.973, 2.163 and 2.255) are higher than 1.645. The higher values tells us that there is no statistical significance between the ranking results of the two approaches.

Table 6. Ranking results of the selected twenty machining centers

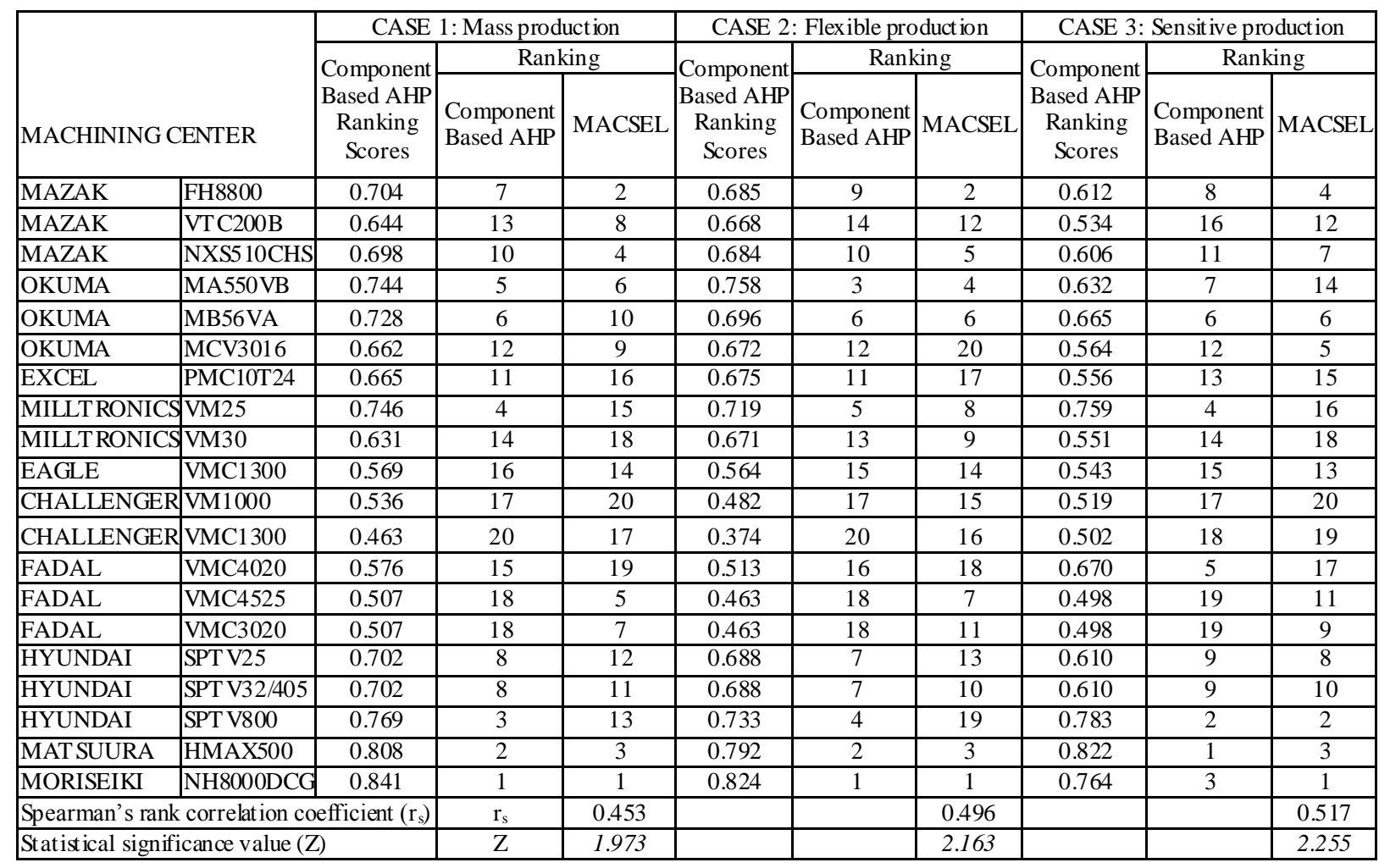

Although the ranking results are not statistically different from each other, the differences in machining centers' rankings increase up to 15 and the average difference in the rankings of the twenty machining centers is 4.5. For example, HYUNDAI SPT800 is ranked third in CASE 1 and fourth in CASE 2 by component based AHP model whereas it is ranked thirtenth in CASE 1 and ninetenth in CASE 2 by MACSEL out of the twenty machining centers. The results show that completely different rankings are provided by the two models for HYUNDAI SPT800. The reason for the differences can be explained by the special components described in HYUNDAI SPT800's catologue. It is revealed in the catologue that HYUNDAI SPT800's spindle component is 'rigidly supported at three points by two sets of cylindrical roller bearing and one set of angular contact bearings and the spindle bearings are grease packed to minimize heat generation and hydraulic fluid that circulates in the headstock is cooled by the chiller unit' (Hyundai Heavy Industries Co.Ltd., 2007). Similarly HYUNDAI SPT800's structure is described as a 'single casting and the mounting surfaces of the $\mathrm{X}$ and $\mathrm{Z}$ axess linear bearings are machined in the same set-up for extremely high precision' (Hyundai Heavy Industries Co. Ltd., 2007). The component based AHP model captures the special components of HYUNDAI SPT800 by assigning high performance scores in HYUNDAI SPT800's row (No 18) in Table 3. However, the technical specification values can not capture the described machining performance of HYUNDAI SPT800 with the given accuracy values which are close to other machining centers' values. The real performance of the HYUNDAI SPT800 can be determined by not technical specification values but by its components. This example illustrates the advantages of using components instead of technical specification values in ranking machining centers especially when they will be used in special conditions such as 'heavy duty machining' or 'using continuously long time durations'. 


\section{Conclusion}

The component based AHP model provides an alternative approach to the selection models that use technical specification values and it is especially recommended, when the machining center will be used under heavy conditions such as machining heavy workparts for long time durations. It should be noted in using an AHP model is that the success of the ranking results is sensitive to the correct selection of weighting numbers in filling pairwise comparison matrix. The pair wise importance values are assigned subjectively; and hence their correctness depends on the users' knowledge and familiarity with the conditions and production type of the machining center usage.

\section{REFERENCES}

Arslan, M.C., Catay, B., Budak, E. (2002). Decision Support System for machining center selection in: A. Baykasoglu and T. Dereli (eds.), Proceedings of ICRM-2002, $2^{\text {nd }}$ International Conference on Responsive Manufacturing, University of Gaziantep, Turkey, 752-757.

Ayağ, Z., Özdemir, R.G., An intelligent approach to machining center selection through fuzzy analytic network process, Journal of Intelligent Manufacturing, DOII0.1007/s10845-009-0269-7, 2011

Cimren, E., Budak, E., Catay, B. (2004). Development of a machining center selection system using analytic hierarchy process, Intelligent Computation in Manufacturing Engineering, 4, 1-10.

Georgakellos, D.A. (2005). Technology selection from alternatives: a scoring model for screening candidates in equipment purchasing, International Journal of Innovation and Technology Management, 2(1), 1-18.

Hyundai Heavy Industries Co., Ltd. (2007). Horizantal Machining Centers, SPT-H800 specifications. $<$ http://www.hyundai-engine.com>

Ic, Y.T., Yurdakul, M. (2009). Development of a decision support system for machining centers election, Expert Systems with Applications, 36, 3505-3513.

Irath, MMc, Romero, A. (2005). Advanced bearing for high-speed machining, The Timkon Co. Coventry, U.K. www.machinedesign.com/artic les.

Lin, Z-C., Yang, C-B. (1996). Evaluation of machine selection by the AHP method, Journal of Materials Processing Technology, 57, 253-258.

Oeltjenbruns, H., Kolarik, W. J., Schnadt-Kirschner, R. (1995). Strategic planning in manufacturing systems- AHP application to an equipment replacement decision, International Journal of Production Economics, 38, 189-197.

Sun, S. (2002). Assessing computer numerical control machines using data envelopment analysis, International Journal of Production Research, 40(9), 2011-2039.

Tlusty, G. (2000). Manufacturing Processes and Equipment, Chapter 7-10, Printice Hall, US.

Vasilash, G.S. (1997). Machining center selection made simple, Automotive Manufacturing \& Production, 109(3), 66-67.

Yurdakul, M. (2004). AHP as a strategic decision-making tool to justify machining center selection, Journal of Materials Processing Technology, 146, 365-376. 